\title{
El ekuaro: un sistema agroforestal tradicional michoacano*
}

\section{The ekuaro: a traditional agroforestry system michoacano}

\begin{abstract}
Arturo Franco-Gaona ${ }^{1}$, Benito Ramírez-Valverde ${ }^{1}$, Artemio Cruz-León ${ }^{2 \S}$, Dora Ma. Sangerman-Jarquín ${ }^{3}$, José Pedro JuárezSánchez ${ }^{1}$ y Gustavo Ramírez-Valverde ${ }^{4}$

${ }^{1}$ Colegio de Postgraduados-Campus Puebla.Carretera Federal México-Pueblakm 125.5,72760,Puebla,Puebla.(bramirez@colpos.mx; pjuarez@colpos.mx).²Universidad Autónoma Chapingo. Carretera México-Texcoco, km 38.5, Chapingo, Estado de México, C.P. 56230. México. Tel: 595952 1621.(etnoagronomia1@gmail.com). ${ }^{3}$ Campo Experimental Valle de México- Instituto Nacional de Investigaciones Forestales, Agrícolas y Pecuarias. Los Reyes- Texcoco, km 13.5, A. P. 10, C. P. 56250. Coatlinchán, Texcoco, Estado de México. Tel. 018000882222 Ext. 85353. ${ }^{4}$ Colegio de Postgraduados. Carretera México-Texcoco, km 36.5 Montecillo, Estado de México. Tel. 595 9520 200. (gramirez@colpos.mx). ${ }^{\S}$ Autor para correspondencia: fagamex@yahoo.com.mx.
\end{abstract}

\begin{abstract}
"en el periodo que estuve en la escuela, durante el temporal de lluvias, los sábados o domingos acompañaba a mi abuelo Francisco Cárdenas Pacheco a su "ecuaro" de dos hectáreas de terreno inclinado, situado en las faldas del cerro de San Francisco, terreno que rentaba sembrándolo de maíz, frijol y calabaza; trabajaba la tierra empleando el azadón, el arado no se utilizaba por lo pedregoso del terreno. En la siembra y escarda yo tomaba parte con el azadón hasta donde lo permitían mis fuerzas"
\end{abstract}

Lázaro Cárdenas: apuntes...

\section{Resumen}

El ekuaro, ecuaro o ekuarhu (ekuaru = patio) es un sistema etnoagroforestal tradicional complejo propio del estado de Michoacán y de los P'urhépechas o Tarascos, que según sus cultivadores puede formar parte de la vivienda, ya que se interrelaciona con el hogar, la troje, la crianza y explotación de ganado, mayor y menor, la agricultura y algunas especies forestales; o encontrarse en las laderas de los cerros con cultivo de maíz y otras especies asociadas, sin roturación del suelo, ya que su escasa profundidad, presencia de piedras y altas pendientes lo impiden. Con el objetivo de reunir información del ekuaro como un sistema etnoagroforestal tradicional, desarrollado por los Tarascos o P'urhépechas y heredado a sus descendientes actuales con tendencia a desaparecer, se partió de la evidencia empírica de campo del Valle MoreliaQueréndaroy de sistematización bibliográfica para construir un marco conceptual clasificatorio e identificar su importancia y problemática como espacio sociocultural tradicional. Se

\section{Abstract}

The ekuaro, ecuaro or ekuarhu (ekua.uu=yard) is a traditional ethnoagroforestry own complex system of the state of Michoacán andP'urhépechas orTarascos, which according to its growers can be part of the housing as it interrelates with the home, the barn, breeding and cattle farm, wholesale and retail, agriculture and some forest species; or found in the hillsides with maize and other associated species without tilling the soil, because their shallowness, presence of stones and steep slopes prevent it. With the aim of gathering information ethnoagroforestry ekuaro as a traditional system, developed by Tarascos or P'urhépechas and their current descendants inherited tendency to disappear, we started from the empirical evidence Valley field Morelia-Queréndaro and literature systematization qualifier to build a conceptual framework and identify its importance and problematic as traditional sociocultural space. It is classified and characterized the ekuaro and progress as huamil among the nahuatl. As

\footnotetext{
* Recibido: diciembre de 2015

Aceptado: marzo de 2016
} 
clasifica y caracteriza al ekuaro y su avance como huamil entre los náhuatl. Como sistema agrícola tradicional se aprecia que el ekuaro es diverso y multifuncional, por lo que se propone una clasificación con base en su ubicación y el tipo de tecnología utilizada, en: a) ekuaro tipo patio, solar, huerto o jardín y b) ekuaro de explotación agroforestal asociado al ganado; c) ekuaro tipo huamil;yd) ekuaro de terreno de cultivo intensivo. En ellos se cultiva la milpa y conserva el maíz de ekuaro o uarhuti en riesgo de desaparecer.

Palabras clave: clasificación, historia, huerto familiar, maíz, P'urhépechas.

\section{Introducción}

La aparición de la agricultura en México ocurrió hace más de ocho mil años. Esta antigüedad le permite poseer una diversidad de plantas, animales y tecnologías, resultado de las complejas condiciones ambientales que caracterizan al país y a la permanencia de más de 60 grupos étnicos en su territorio; quienes ostentan diferentes formas de hacer agricultura, basada en la experiencia social (prácticas y saberes) de la que son protagonistas, alejada de la lógica de la monocultura del saber y del rigor científico (Santos, 2009). Son pueblos autóctonos cuya población suma cerca de 10.22 millones (Comisión Nacionl para el Desrrollo de los Pueblos Indígens (CDI, 2006), quienes por siglos han construido habilidades y experiencias de desarrollo en el manejo de sus espacios habitacionales y de producción.

Estas prácticas, experiencias y saberes tecnológicos continuamente se confrontan y enriquecen, mediante procesos para la selección, cuidado, recolección y manejo de diversos cultivos; resultando una transformación antropogénica del paisaje (Caballero y Cortés, 2001). De esta forma, los pueblos y comunidades buscan recrear el ambiente natural en su vivienda, al plantar especies de importancia socio-económica y con características agroforestales en sus huertos, jardines, solares, patios frontales y en terrenos marginales, convirtiéndolos en verdaderos agrosistemas, que cuidan y al mismo tiempo obtienen algunos frutos y cosechas pequeñas de cultivos como parte de la economía familiar (Santana, 1986).

Estas representaciones espaciales suelen ser distintivas para cada estado, región y grupo indígena y mestizo del país, donde se han generado y explotan diferentes traditional farming system shows that the ekuaro is diverse and multifunctional, so that a classification based on their location and type of technology used in it is proposed: a) ekuaro type courtyard, solar, orchard or garden b) ekuaro of agroforestry associated with livestock; c) ekuarohuamil type; and d) ekuaro intensive cultivation of land. In them the corn is grown and canned corn uarhuti ekuaro or at risk of disappearing.

Keywords: classification, corn, family garden, history, P'urhépechas.

\section{Introduction}

The emergence of agriculture in Mexico occurred more than eight thousand years ago. This age allows you to have a diversity of plants, animals and technologies, result of complex environmental conditions that characterize the country and to the permanence of more than 60 ethnic groups in its territory; those who hold different ways of doing agriculture, based on social experience (practical and knowledge) of which they are protagonists, away from the logic of the monoculture of knowledge and scientific rigor (Santos, 2009). They are indigenous peoples whose population totals about 10.22 million (National Commission for development of Indigens Peoples (CDI, 2006), who for centuries have built skills and development experience in the management of their living spaces and production.

These practices, experiences and technological knowledge continually confront and enrich, through processes for selection, care, collection and management of various crops; resulting in an anthropogenic landscape transformation (Caballero and Cortés, 2001). Thus, peoples and communities seek to recreate the natural environment in the home, by planting species of socio-economic importance and agroforestry features in their orchards, gardens, plot, front yards and on marginal land, making true agrosystems, which care and at the same time get some fruits and small harvests crops as part of the family economy (Santana, 1986).

These spatial representations are usually distinctive for each state, region and indigenous and mestizo group in the country, which have been generated and exploit different traditional agricultural, livestock and forestry systems, developed in various cultural and environmental contexts. As shown Moreno-Calles et al. (2013), describing 13 systems located in different states, within which the ekuaro 
sistemas agrícolas, pecuarios y forestales tradicionales, desarrollados en contextos culturales y ambientales diversos. Como lo muestra Moreno-Calles et al. (2013), al describir 13 sistemas, ubicados en diferentes estados del país, dentro de los cuales se encuentra el ekuaro -en la literatura se encontraron varias formas de escribir ecuaro, ekuaro, ekuarho y ekuarhu, refiriéndose a lo mismo, en este escrito se utiliza la palabra ekuaro y se respetan las formas escritas en los textos originales tomados como referencia; ocurriendo lo mismo con la palabra purépecha o P'urhépecha-. Cuya importancia radica en ser un sistema tradicional que se aleja de las relaciones de producción capitalista, propio del estado de Michoacán y su cultura P'urhépecha; que desde la época de la colonia, al igual que otros sistemas agrícolas tradicionales, ha sido marginado, al grado de que se está perdiendo o modificando debido a la falta de interés y políticas agrícolas que los protejan; y por la implementación del paradigma dominante de la ciencia moderna, que considera que el uso de un paquete tecnológico en la agricultura es la solución al hambre y pobreza en que se encuentran sumidos los pueblos y comunidades del país. Pero debido a las condiciones fisiográficas donde habitan es prácticamente imposible aplicarlo. Por lo que resulta que las formas tradicionales de manejo tecnológico usadas por las comunidades indígenas y mestizas para producir son más versátiles.

Ante el riesgo de perder los espacios tradicionales de cultivo, existe la necesidad de estudiarlos en profundidad, con base a la ecología de los saberes y de las productividades, que de acuerdo a Santos (2009) y la sociología de las ausencias, son lugares cargados de conocimientos que requieren conservarse, apegados a las prácticas cognitivas de las clases, los pueblos y los grupos sociales que han sido históricamente victimizados, explotados y oprimidos por el colonialismo y capitalismo globales. Que al ser invadidos por la modernidad con la implementación de la Revolución Verde y sus principios, desde los años 50 del siglo pasado, como la única opción tecnológica posible de desarrollo y buen vivir, resultó una incongruencia. Ente ello es obligatorio construir un proceso de descolonización cultural, con el fin de recuperar los saberes agrícolas tradicionales y evitar un epistemicidio.

Aquí las etnociencias o estudio sobre saberes o conocimientos de los grupos nativos pueden serútiles, como la etnoagroforestería y la etnoagronomía. Ciencias que se proponen como alternativa a los actuales conocimientos productivos modernos, provenientes de la investigación y -in literature is found several ways to write ecuaro, ekuaro, ekuarho and ekuarhu, referring to the same, in this paper used the word ekuaro and forms written in the original texts taken as reference are respected; happening the same with the Purepecha word or P'urhépecha-. Whose importance lies in being a traditional system that moves away from capitalist relations of production, typical of the state of Michoacan and culture P'urhépecha; that from the time of the colony, like other traditional farming systems, it has been marginalized, to the extent that is being lost or modified because of the lack of interest and agricultural policies that protect them; and the implementation of the dominant paradigm of modern science, which considers the use of a technology package in agriculture is the solution to hunger and poverty in the towns and communities across the country are mired. But because of the physiographic conditions where they live is virtually impossible to apply. So it was that traditional forms of technological management used by indigenous and mestizo communities to produce more versatile.

At the risk of losing traditional growing areas, there is a need to study them in depth, based on the ecology of knowledge and productivities, which according to Santos (2009) and the sociology of absences, are places full requiring knowledge retained, attached to cognitive practices of classes, peoples and social groups that have been historically victimized, exploited and oppressed by colonialism and global capitalism. That they are invaded by modernity with theimplementation of the Green Revolution and its principles, since the 50 s of the last century, as the only possible option technological development and good living, it was an incongruity. This entity is required to build a cultural decolonization process in order to recover traditional agricultural knowledge and avoid epistemicide.

The ethnosciences or study on knowledge or knowledge of native groups may be useful, such as ethnoagroforestry and ethnoagronomy. They proposed as an alternative to today's modern productive knowledge, from research and higher agricultural education, which dominates the view of western science and excessive use of inputs (seeds and agrochemicals) affecting economically to a segment science widely marginalized majority of production units in Mexico. Is considered that $100 \%$ of agricultural producers in the country, $66 \%$ are among the laborers subsistence and transition who exploit small properties and have a precarious adoption of modern technological elements; that a lack of financial support and research to enable community development adds, because apparently these units are not within the scope or interest of government programs (Cruz et al., 2015). 
educación agrícola superior, donde domina la visión de la ciencia occidental y el uso excesivo de insumos (semillas y agroquímicos) que afectan en lo económico a un segmento ampliamente mayoritario de unidades de producción marginadas en México. Se considera que de 100\% de los productores agrícolas del país, $66 \%$ se ubican entre los jornaleros de autoconsumo y transición, quienes explotan pequeñas propiedades y tienen una adopción precaria de elementos tecnológicos modernos; a los que se suma una falta de apoyos financieros y de investigación que permitan el desarrollo comunitario, pues al parecer estas unidades no se encuentran dentro del alcance o interes de los programas gubernamentales (Cruz et al., 2015).

El objetivo del trabajo consiste en reunir información del ekuaro o ecuaro como un sistema agroforestal tradicional, desarrollado por el pueblo tarasco o $\mathrm{P}^{\prime}$ urhépecha y heredado a los descendientes actuales de esta etnia, con evidencias de una tendencia a desaparecer, por ello, estudiarlo permitirá vislumbrar su funcionamiento, posibilidades de conservación y su papel para favorecer el desarrollo agrícola comunitario alternativo a la óptica capitalista y con apego al buen vivir; ya que por sus cualidades tecnológicas, económicas y sincrética ha trascendido y demostrado su efectividad para proporcionar satisfactores a sus cultivadores.

La importancia del ekuaro radica en que es un sistema de cultivo tradicional que contribuye a la autosuficiencia y bienestar de las familias P'urhépechas y es clave en su seguridad alimentaria (Godínez y Casas, 2014). Es una evidencia del uso eficiente de terrenos marginales y de generación de una tecnología apropiada a las condiciones en donde se desarrolla; y un sistema vulnerable en riesgo de desaparecer por la modernización tecnológica, migración y políticas públicas que no lo consideran.

\section{Metodología}

Apartir de la investigación de campo realizada en la región del valle Morelia-Queréndaro, donde se observa la presencia de estrategias productivas en terrenos marginales con pendientes elevadas y de piedras abundantes que impiden el laboreo agrícola con animales de trabajo o maquinaria, se exploró el conocimiento empírico en campo y fundamentalmente en la bibliografía para caracterizar el ekuaro. Apartir de la revisión documental se hizo una sistematización de la literatura para
The aim of this work is to gather information ekuaro orecuaro as a traditional agroforestry system, developed by the people tarasco or P'urhépecha and inherited the modern descendants of this ethnic group, with evidence of a tendency to disappear, therefore, study it will allow glimpse operation, conservation possibilities and its role to promote agricultural development community alternative to capitalist optics and with adherence to good living; as for its technological, economic and syncretic qualities he has transpired and demonstrated their effectiveness in providing satisfactions to their growers.

The importance of ekuaro is that it is a traditional farming system that contributes to self-sufficiency and well-being of families P'urhépechas and is key to food security (Godínezand Casas, 2014). It is an evidence of efficient use of marginal land and generation of appropriate technology to the conditions in which it develops; and a vulnerable system at risk of disappearing due to technological modernization, migration and public policies that do not consider.

\section{Methodology}

From field research conducted in the valley region MoreliaQueréndaro, where the presence of productive strategies on marginal lands with high slopes and rich stones that impede agricultural tilling working animals or machinery is observed, we explored the empirical knowledge in the field and mainly in the literature to characterize the ekuaro. From the document review was a systematization of literature to build a conceptual framework that allowed characterize establish the problems and to classify and identify the different meanings of ekuaro term between michoacanos today and yesterday, and its resemblance to the huamil system Nahúatl.

The valley was considered because in ancient times was occupied by the P'urhépecha culture, which currently houses its vestiges; and different types of agriculture practiced in irrigation, irrigation and temporal tip on flat terrain and bigoted, corn being one of its main crops. It presents a rugged topography, with close to $2000 \mathrm{~m}$ heights, because it crosses the Neovolcanic and the Sierra Madre Occidental. In the Valley's tech agriculture it was introduced around 1960, slowly displacing traditional farming systems.

The study of traditional agriculture in Mexico is an old subject studied anthropology, agronomy, biology and other areas of knowledge related to man and nature, as ethnoagroforestry 
construir un marco conceptual que permitió caracterizarlo, establecer la problemática y hacer una clasificación e identificar las diferentes acepciones del término ekuaro entre los michoacanos de hoy y ayer, y su parecido con el sistema huamil de los náhuatl.

El valle se consideró debido a que en la época prehispánica fue ocupado por la cultura P'urhépecha, donde actualmente se encuentran sus vestigios; y se practican diferentes tipos de agricultura en riego, punta de riego y temporal en terrenos planos y cerriles, siendo el maíz uno de sus principales cultivos. Presenta una topografía accidentada, con alturas cercanas a los $2000 \mathrm{~m}$, debido a que lo cruza el Eje Neovolcánico y la Sierra Madre Occidental. En el Valle se introdujo la agricultura tecnificada alrededor de 1960, desplazando lentamente los sistemas tradicionales de cultivo.

El estudio de la agricultura tradicional en México es un tema añejo estudiado por la antropología, agronomía, biología y otras áreas del conocimiento relacionadas con el hombre y la naturaleza, como la etnoagroforestería y la etnoagronomía. Ello se ha hecho para: conocerla y extraer su tecnología, materiales biológicos y genéticos para "mejorarlos" e introducirlos al mercado; conservar el conocimiento milenario, materiales biológicos, cultura y relaciones sociales que existen entre el hombre y el manejo sustentable de la naturaleza; y utilizarla como elemento explicativo del desarrollo comunitario. Lo que ha sido insuficiente, porque no se han mostrado propuestas a fondo para su recuperación y conservación.

Wilken (1987), refiriéndose a la agricultura tradicional, menciona que la esencia del término tradicional se encuentra en la forma en que se transfieren los conocimientos, de una generación a otra de manera verbal e informal y a través de intercambios individuales, vecinales y comerciales; a diferencia de como se hace con la agricultura moderna, cuya diseminación es más visible debido al extensionismo que la promueve. Un sistema agrícola tradicional es un diseño físico de cultivos anuales y perennes intercalados, con animales en el espacio y a través del tiempo, que al ser manejados por el hombre, de acuerdo a su propia cosmovisión y tecnología, se vuelve etnoagroproductivo y etnoagroforestal, donde se ha generado, desarrolla y conserva la biodiversidad cultural (Moreno-Calles et al. 2013), y se encuentran los sistemas relacionados con los huertos familiares, solares, patios y jardines como el ekuaro. and ethnoagronomy. This has been done to: know and extract its technology, biological and genetic materials to "improve" and introduce them to the market; preserve ancient knowledge, biological materials, culture and social relations that exist between man and sustainable management of nature; and use it as an explanatory element of community development. Has been insufficient, because they have not shown depth proposals for recovery and conservation.

Wilken (1987), referring to traditional agriculture, mentions that the essence of the traditional term is in the way knowledge from one generation to another orally and informally and through individual, neighborhood and trade are transferred; unlike as is done with modern agriculture, whose dissemination is more visible due to extensionism that promotes it. A traditional farming system is a physical design of annual and perennial crops interspersed with animals in space and over time, that being handled by man, according to their own worldview and technology it becomes ethno agroproduction and ethnoagroforestry where it has generated, develops and retains the cultural biodiversity (Moreno-Calles et al.2013), and are those related to home gardens, solar, yards and gardens as ekuaro systems.

\section{Ethnoagroforestry traditional systems}

The agroforestry, according to Farrell andAltieri(1997), "is the generic name used to describe a system using the ancient land and widely practiced, in which the trees are combined spatial and / or temporarily with animals and agricultural crops". Krishnamurthy and Ávila (1999) define it as the science that studies the systems, agroforestry practices, interactions and emergent properties of the components of these land forms; that interact with humans, orders management and makes a profit, turning ethnoagroforestry systems, history and own culture, related to man or ethno prefix that has been taken with relative ease to refer to the use of traditional knowledge as source of knowledge, forming the calls ethnosciences (Perdomo, 2013).

The ethnoagroforestry is a scientific area recently created with the study of traditional agroforestry systems, created, developed and managed by indigenous and peasant communities and "Rancherías" (Moreno-Calles et al., 2014). The ethnoagronomy is that science gathers the views and aspirations of producers and aligned in the construction of alternatives to rural development; and it is defined as the ethnoscience that deals with the study of knowledge that indigenous and mestizo peasants put into practice 


\section{Sistemas etnoagroforestales tradicionales}

La agroforestería, según Farrell y Altieri (1997): “es el nombre genérico utilizado para describir un sistema de uso de la tierra antiguo y ampliamente practicado, en el que los árboles se combinan espacial y temporalmente con animales y cultivos agrícolas". Krishnamurthy y Ávila (1999) la definen como la ciencia que estudia los sistemas, las prácticas agroforestales, las interacciones y propiedades emergentes de los componentes de estas formas de la tierra; que al interaccionar con el hombre, ordena su manejo y obtiene un beneficio, volviéndose sistemas etnoagroforestales, con historia y cultura propia, relacionados con el hombre o etno-, prefijo que ha sido asumido con relativa facilidad para referirse a la utilización del conocimiento tradicional como fuente de saber, conformando las llamadas Etnociencias (Perdomo, 2013).

La etnoagroforestería es un área científica de reciente creación que se encarga del estudio de los sistemas agroforestales tradicionales, creados, desarrollados y manejados por comunidades indígenas, campesinas y rancheras (Moreno-Calles et al., 2014). La etnoagronomía es la que ciencia recoge las visiones y aspiraciones de los productores y se alinea en la construcción de alternativas al desarrollo rural; y se define como la Etnociencia que se encarga del estudio de los saberes que los campesinos indígenas y mestizos ponen en práctica durante los proceso de aprovechamiento de los recursos naturales, por medio de las actividades agrícolas, pecuarias, forestales y de la fauna para obtener los satisfactores antropocéntricos necesarios para su subsistencia, reproducción social y desarrollo (Cruz et al., 2015).

Los sistemas etnoagroforestales tradicionales, como formas tecnológicas que interactúan entre el hombre, la tierra, los cultivos y ciertas especies de animales domésticos, son importantes porque están integrados a estrategias múltiples de uso, proveen diversos beneficios a los seres humanos a escala local, regional y global; conservan especies endémicas y de importancia cultural e integran, recrean las cosmovisiones, conocimientos, prácticas y reglas de uso tradicionales (Moreno-Calles et al., 2013) y tienen un mínimo uso o nulo de insumos provenientes de la agricultura moderna.

Con el paso del tiempo estos sistemas han sufrido modificaciones socio-económicas y ambientales, inducidas por cambios en el paisaje rural, que tiende a ser during the process of exploitation of natural resources, through agriculture, livestock, forestry and wildlife for the satisfactory anthropocentric necessary for their survival, social reproduction and development (Cruz et al., 2015).

Traditional systems ethnoagroforestry, such as technological forms that interact between man, land, crops and certain species of pets, are important because they are integrated multiple-use strategies, provide various benefits to humans at local, regional and global; endemic and preserve cultural and integrate important species, recreating the world views, knowledge, practices and rules of traditional use (MorenoCalles, Toledo and Casas, 2013) and have minimal or no use of inputs from modern agriculture.

Over time these systems have suffered socio-economic and environmental changes induced by changes in the rural landscape, which tends to be increasingly urban within communities, because of the need for land distribution, that being inherited children, fractionate and tend to change their use; but especially by the totalitarian model of rationality presiding modern science, which denies the rational character to all forms of knowledge not guidelines for its epistemological principles and methodological rules; situation that causes loss and transformation of generational worldview and knowledge of common, practical or common sense, product neat experience (Santos, 2009); that due to the lack of interest in conservation, end in abandonment, disappearance and estrangement from nature. Before it is not possible to lose in such a short time something that has taken hundreds of years to build selectively in the biological and productive.

The importance of these systems is that: 1) are points of conservation of species and germplasm; 2) are centers of knowledge generation that have rules of use and adherence to various socio-ecological factors; 3 ) are spaces to support the economy and reducing hunger and poverty; 4) exploitation allows full use of marginal lands, which if not made, would remain barren and unproductive, and local surplus labor and family labor; 5) maintain a continuity of prehispanic elements with modern, whose study is feasible technological, ecological, cultural and comparisons (Palerm, 1997; MorenoCalles et al., 2013); and 6) maintains a balance between nature and the needs and rights of human beings with adherence to the principle of good living, whose vision assumes other knowledge and practices, questioning the Western concept of wellness and colonialist of power, erosion agricultural and wild biodiversity, and over-exploitation of 
cada vez más urbano dentro de las comunidades, debido a la necesidad de repartición de la tierra, que al ser heredada a los hijos, se fraccionan y tienden a cambiar su uso; pero sobre todo por el modelo totalitario de racionalidad que preside la ciencia moderna, que niega el carácter racional a todas las formas de conocimiento que no se pauten por sus principios epistemológicos y por sus reglas metodológicas; situación que origina pérdida y transformación de la cosmovisión generacional y de un conocimiento del sentido común, práctico o vulgar, producto de la experiencia ordenada (Santos, 2009); que debido a la falta de interés en su conservación, concluyen en el abandono, desaparición y alejamiento de la naturaleza. Ante ello no es posible perder en tan poco tiempo algo que ha tardado cientos de años en construirse de manera selectiva en lo biológico y productivo.

La importancia de estos sistemas radica en que: 1) son puntos de conservación de especies y germoplasma; 2) son centros de generación de conocimientos que cuentan con reglas de uso y apego a diversos factores socio-ecológicos; 3) son espacios de apoyo a la economía y a la disminución del hambre y pobreza; 4) su explotación permite un aprovechamiento íntegro de las tierras marginales, que de no hacerse, permanecerían baldías e improductivas, y de los excedentes de mano de obra local y familiar; 5) mantienen una continuidad de elementos prehispánicos con los modernos, de cuyo estudio es factible realizar comparaciones tecnológicas, ecológicas, culturales y más (Palerm, 1997; Moreno-Calles et al., 2013); y 6) mantiene un equilibrio entre la naturaleza y las necesidades y derechos de los seres humanos con apego al principio del buen vivir, cuya visión asume otros saberes y prácticas, al cuestionar el concepto occidental de bienestar y colonialidad del poder, la erosión de la biodiversidad agrícola y silvestre, y la sobre explotación de la naturaleza; considerada como "capital natural" y no como componente equitativo de vida y desarrollo ajeno al de los países industrializados (Acosta, 2010).

\section{Caracterización del ekuaro}

El ekuaro es una conformación fisiográfica del terreno que puede ser plano o presentar una pendiente pronunciada. Se caracteriza por formar parte del patio de la casa, según lo muestra su traducción del P'urhépecha o tarasco al español ekuarhu [ekua.ru], equivale a "patio" (Lathrop, 2007), que al contextualizarlo se puede entender como "el lugar donde se ve ámpliamente", o sea el todo. Es una prolongación de la habitación purépecha, donde se encuentra la troje, la nature; considered as "natural capital" and not as equitable component life and outside development the industrialized countries (Acosta, 2010).

\section{Characterization ekuaro}

The ekuaro is a physiographic conformation of the land that can be flat or have a steep slope. It is characterized by being part of the courtyard of the house, as shown by his translation of P'urhépecha or Tarascan to Spanish ekuarhu [ekuaru], equivalent to "yard" (Lathrop, 2007), which to contextualize it can be understood as "the place which is largely "that is the whole. It is an extension of the Purepecha room, where the granary, raising cattle and sheep and practice crop association of different strata around the house, whose delimitation is given through vegetation and the arrangement of stones. It is rich in traditional knowledge, as it is largely related to daily life, nature and the management of it is inside. For example, Barrera-Bassols(2003) describes, temporarily, cultural activities undertaken to 17 species of laminated edible plants located in a ekuaro in Pichátaro, Michoacán, where includes arvensis, the cornfields and fruit.

Ekuaro on Several assertions, all related to its location, climate, physiography, technology, culture and intensity of land use. Sánchez (2002); Moreno-Calles et al. (2013) mention that the ekuaro is an orchard located near or next to the house, with many species of perennials and annuals (corn, beans, vegetables, fruit plants and other intensively cultivated plants) associated with wild animals and sometimes, managed mainly women and children; and it is found in temperate climates and warm humid Michoacán.

For Barrera-Bassols (2003) the ekuaro is a "homegarden system", a sophisticated agro-silvocultural system, intensive exploitation, which includes trees, shrubs, herbaceous; whose architecture resembles forests and works as an ecological system; are small experimental plots, close to half a hectare, where you can find more than 50 domesticated plants, semi-domesticated, tolerated and even wild; used for food, medicinal, aromatic and religious purposes. In it there is no use of chemical fertilizers and herbicides and the land is cultivated and worked mainly with the hoe.

Santana (1986) mentions that the "ecuaro" is always conceived as a space adjacent to housing, which is primarily the domain of animals (major and minor), a sort of outdoor stall; which it has evolved from "frustrated" way to the former site of Spanish descent, due to the adoption of some plant species, expressions and crop planters. On the 
crianza de ganado mayor y menor y practica la asociación de cultivos de diferentes estratos alrededor de la casa, cuya delimitación está dada pormedio de vegetación y el acomodo de piedras. Es rico en saberes tradicionales, ya que se encuentra ampliamente relacionado con la vida cotidiana, la naturaleza $\mathrm{y}$ al manejo que de ella se hace en su interior. Por ejemplo, Barrera-Bassols (2003) describe, de manera temporal, las actividades culturales que se realizan a 17 especies de plantas comestibles estratificadas ubicadas en un ekuaro, en Pichátaro, Michoacán, donde incluye arvensis, la milpa y frutales.

Sobre el ekuaro exísten varias aseveraciones, todas relacionadas con su ubicación, clima, fisiografía, tecnología, cultivos e intensidad de uso del suelo. Sánchez (2002); Moreno-Calles et al. (2013) mencionan que el ekuaro es un huerto que se encuentra cerca o al lado de la casa, con múltiples especies de plantas perennes y anuales (maíz, frijol, vegetales, frutales y otras plantas cultivadas de manera intensiva) asociadas con silvestres y en ocasiones con animales, manejado princialmente por mujeres y niños; y que se encuentra en los climas templados y cálido humedos de Michoacán.

Para Barrera-Bassols (2003) el ekuaro es un "homegarden system", un sofisticado sistema agro-silvocultural, de explotación intensivo, que integra árboles, arbustos, herbaceas; cuya arquitectura semeja a los bosques y funciona como sistema ecológico; son pequeñas parcelas experimentales, cercanas a la media hectárea, donde es posible encontrar más de 50 plantas domesticadas, semidomesticadas, toleradas e incluso salvajes; utilizadas con fines alimenticios, medicinales, aromáticas y religiosos. En él no hay uso de fertilizantes químicos ni herbicidas y la tierra es trabajada y cultiva principalmente con la azada.

Santana (1986) menciona que el "ecuaro" se concibe como un espacio siempre adyacente a la vivienda, que es ante todo el dominio de los animales (grandes y menores), una suerte de establo al aire libre; el cual ha evolucionado de manera "frustrada" hacia el antiguo solar de filiación española, debido a la adopción de algunas especies vegetales, de expresiones jardineras y de cultivos. Sobre el solar Aguilar y Prieto (2002) dicen que "el solar familiar, limitado por una cerca de piedra, está constituido por la troje que a través de un pórtico abre hacia el patio interior, donde los habitantes realizan la mayor parte de sus actividades, cuenta con huerto y a veces con aves de corral". Definiciones que lo muestran como un espacio multifuncional, productivo, recreativo, habitable y resguardador de alimentos. solar Aguilar and Prieto (2002) say that "the family plot, bounded by a stone fence, consists of the barn that through a porch opens onto the courtyard, where people do most of their activities, has garden and sometimes with poultry. " Definitions showing him as a multifunctional space, productive, recreational, living and preservation food.

The General Lázaro Cárdenas reminds the "ecuaro" as a breeding ground sloped, located on the slopes of the hill, his grandfather rented to plant corn, beans and squash with a hoe. The plow was not used so rocky terrain, which became very hard work it (Cárdenas del Río, 2003).

As you can see, there are several types of ekuaro and each has particular characteristics, which adds that it is a space of family life and social relations; whose use persists in virtually all of the region occupied by the Tarasco Purépecha Empire or the pre-hispanic world, which covered more than $75000 \mathrm{~km}^{2}$ in the highlands of west-central Mexico region. Who because of his military-expansionist behavior they attempted to occupy the territory of the Aztecs, who responded penetrating to the territorial heart of the Tarascan up to Charo where possible, or knew the system ekuaro in the hills and houses or brought the huamil and they were practical implemented. Which would be very interesting elucidating from the point ethnohistoric which system came first. For example in Cortazar, Guanajuato, older residents recognize the presence of ekuaro in the hillsides where they planted corn and beans, mainly.

\section{Ekuaro and technology}

Although there is information on the type of land and where the ekuaro is grown, the type of tenure or category to which he belonged in the Tarascan Empire is unknown; i.e. if the patrimonial lands of the royal dynasty (uacúsecha), to the land allocated to the local lords or the land of ordinary people. In colonial times were marginal pieces of land were allocated to farmers for their own exploitation. Today they can be found in any kind of possession.

The tools used by the P'urhépechas to cultivate their ekuaros were lytic type and some metal. This being important because they were the ones who were more advanced than the other Mesoamerican peoples, who worked gold and silver mainly metallurgical industry. The P'urhépecha worked particularly copper and bronze alloy. With him they manufactured pliers, awls, axes, hoes and other tools to work the land (Uribe, 1996; Roskamp, 2003). 
El General Lázaro Cárdenas recuerda al "ecuaro" como un terreno de cultivo con pendiente, situado en las faldas del cerro, que su abuelo rentaba para sembrar maíz, frijol y calabaza con el azadón. Que el arado no se utilizaba por lo pedregoso del terreno, lo cual volvía muy arduo trabajarlo (Cárdenas del Río, 2003).

Como se puede apreciar, existen varios tipos de ekuaro y cada uno de ellos posee características particulares, a las cuales se suma que es un espacio de convivencia familiar y de relaciones sociales; cuyo uso persiste en prácticamente toda la región ocupada por el Imperio Tarasco o P'urhépecha en el mundo prehispánico, el cual abarcaba más de $75000 \mathrm{~km}^{2}$ en las tierras altas de la región centro-occidente de México. Quienes debido a su conducta militar-expansionista intentaron ocupar el territorio de los Aztecas, quienes respondieron penetrando hasta el corazón territorial de los tarascos a la altura de Charo donde posiblemente, o conocieron el sistema del ekuaro en los cerros y casas o trajeron el huamil e implementaron se práctica. Lo cual sería muy interesante elucidar desde el punto etnohistórico qué sistema surgió primero. Por ejemplo en Cortazar, Guanajuato, los habitantes de mayor edad reconocen la presencia del ekuaro en las faldas de los cerros donde sembraban maíz $\mathrm{y}$ frijol, principalmente.

\section{Ekuaro y tecnología}

Apesar de existir información sobre el tipo de tierras y lugar donde se cultiva el ekuaro, se desconoce el tipo de sistema de tenencia o categoría a que pertenecía en el imperio tarasco; es decir: si a las tierras patrimoniales de la dinastía real (uacúsecha), a las tierras asignadas a los señores locales o a la tierras de la gente común. En época de la colonia eran pedazos de tierra marginal que se asignaban a los campesinos para su propia explotación. En la actualidad pueden encontrarse en cualquier tipo de tenencia.

Las herramientas que utilizaban los $\mathrm{P}^{\prime}$ urhépechas para cultivar sus ekuaros eran de tipo lítico y algunas de metal. Siendo esto importante porque fueron los únicos que tuvieron una industria metalúrgica más avanzada que la de los otros pueblos mesoamericanos, quienes trabajaban el oro y la plata principalmente. Los P'urhépecha trabajaron particularmente el cobre y su aleación el bronce. Con él fabricaron pinzas, punzones, hachas, azadas y otras herramientas para labrar la tierra (Uribe, 1996; Roskamp, 2003).
Iftheekuarospeak, would tellus storiesof survivalandeconomy. Begin with the attacks that have suffered from the conquest, technological changes of modern agriculture and urban growth; which they have been made in an effort to introduce a "more productive technological development" or disappear him slowly. This situation can produce counterproductive effects, it is known that the aim of increasing production and productivity is to create economic, social and political power (Urquidi, 1981); more economic dependence and pollution due to intensive use of inputs and lack of technological selfdetermination with ability to decide the technological direction of a country, or the use of human and material resources to achieve indicttechnology to certain objectives (Urquidi, 1981). When these are not met, the changes initiated usually modify traditional functional structures and put in situation to its users, by new techniques and products, who often put resistance to their dissemination and appropriation.

\section{The ekuaro and corn}

Michoacan as part of the centeroforiginofmaize domestication andmigration route of ethnic groups, has favored the existence of a wide variety of Zea mays $\mathrm{L}$. and their wild relatives. Within this species and varieties such as corn Mushito ekuaro they are. Since imperial times P'urhépecha in sowings different varieties of corn were planted in the cornfield (tarheta) which are mentioned in the relations of Michoacán, written by Fray Jerónimo de Alcalá mid-sixteenth century; and Gilberti (1901), who describe the presence of eight varieties whose classification is based on the consistency and color of grain: dry in ears, white, black, yellow, red, painted colors, tawny, and corn it is done in fifty days. Varieties that have been modified over time by the traditional and modern technology, and the presence of the green revolution in the state. Moreno-Calles et al. (2013); Alarcón-Chaires (2009) also mention that in the ekuaro landraces red, blue cultured and solar or ecuaro purple (uarhuti), in association with beans (kókok). Which they are at risk of disappearing.

\section{Proposal qualifying the ekuaros}

According to his description, the ekuaro may be a production system located within the forest combined with the use of a variety of cultivated wild plants and animals. Found on the hill and worked "hand". Or located within the home and garden, yard or other. The reality is that the ekuaro is a mega-diverse multifunctional system, which covers all the expectations of the authors and producers who can be classified according to its location and technology into four types. 
Si el ekuaro hablara, nos contaría historias de sobrevivencia y economía. Iniciaría con los embates que ha sufrido desde la conquista, de los cambios tecnológicos de la agricultura moderna y del crecimiento urbano; que han sido hechos con el afán de introducirlo en un "desarrollo tecnológico más productivo" o desaparecerlo lentamente. Situación que puede producir efectos contraproducentes, pues se sabe que el objetivo de aumentar la producción y la productividad es crear poder económico, social y político (Urquidi, 1981); más dependencia económica y contaminación, debido aluso intensivo de insumos y la falta de una autodeterminación tecnológica con capacidad para decidir el rumbo tecnológico de un país, o la utilización de los recursos humanos y materiales para lograr encausar la tecnología hasta ciertos objetivos (Urquidi, 1981). Cuando éstos no se alcanzan, los cambios iniciados suelen modificar estructuras tradicionales funcionales y meter en coyuntura a sus usuarios, por las nuevas técnicas y productos, quienes suelen poner resistencia a su difusión y apropiación.

\section{El ekuaro y el maíz}

Como Michoacán forma parte del centro de origen del maíz, domesticación y ruta de migración de grupos étnicos, ha favorecido que exista una amplia variedad de Zea mayz L. y de sus parientes silvestres. Dentro de esta especie se encuentran variedades como el mushito y el maíz de ekuaro. Desde tiempos del imperio P'urhépecha en las sementeras se sembraban diferentes variedades de maízen la milpa (tarheta) las cuales son mencionadas en las Relaciones de Michoacán, escritas por Fray Jerónimo de Alcalá a mediados del siglo XVI; y por Gilberti (1901), quienes describen la presencia de ocho variedades, cuya clasificación se basa en la consistencia y al color del grano en: seco en mazorcas, blanco, negro, amarillo, colorado, pintado de colores, leonado, y maíz que se hace en cincuenta días. Variedades que se han ido modificando a través del tiempo por la tecnología tradicional y moderna, y la presencia de la revolución verde en el estado. Asimismo Moreno-Calles et al. (2013); Alarcón-Chaires (2009) mencionan que en el ekuaro se cultivan maíces nativos de color rojo, azul y el de solar o ecuaro de color morado (uarhuti), en asociación con el frijol (kókok). Los cuales se están en riesgo de desaparecer.

\section{Propuesta clasificatoria del ekuaros}

De acuerdo a su descripción, el ekuaro puede ser un sistema de producción que situado dentro del bosque que se combinaba con el aprovechamiento de una diversidad

\section{Ekuaro plot}

\section{a) Type courtyard, plot, orchards or garden}

Part of the house, like yard, backyard or garden. Its size is usually small. Many of them have Mesoamerican origin, which, in addition to meeting immediate food and economic needs of their owners, are traditional ethnoagroforestry systems, whose origin is prior to the arrival of Europeans in the sixteenth century; that a clash occurred when confronted key ecosystems between the old and the new world(Crosby,2013). Currently he is serving as repositories of local biodiversity, by the existence of a dynamic mix of useful native species. The main function of this ekuaro is to provide a basic source of food and marketable products for the family, which is extremely important given the socioeconomic conditions prevailing today in Mexico and Mesoamerica; because inside there is a mixture of native and exotic, perennial and annual species, distributed in different strata that meet the needs of farmers (Montagnini and Metzel, 2015; Cahuich-Campos et al., 2014).

These spaces, depending on where they are and dwell time, acquire particular names. For example, Guzmán (2005) mentions that in the state of Morelos, the great people they talk to the courtyard called him "callmil" and clarifies that this assignment refers more to growing vegetables on a bed made with soil and manure decomposed and litter, which is no longer practiced; and "calmill" (vegetables in solar), which is a small batch or lot where several varieties of seeds and corn, squash, beans, peppers and flowers are planted. Similarly they are called the small gardens that are located next to the house of the tenants (Palerm, 1997), and the small ekuaro located on the side of the house, where several vegetation strata for particular uses are grown.

\section{b) Continuously ekuaro associated livestock agroforestry}

It is a space of about one hectare, surrounded by a perimeter stone wall, inside which is located the house, the yard or stable livestock and poultry houses. At some points, circling, dividing or off the field, cultivated are plants nopal and maguey pulque. Stuck on stone fences timber, fruit and shade trees are located. Inside, surrounding the house and yard, is the ekuaro as arable land where corn, beans and bean associated with, which works with the team or trunk, as has been without stones is planted. 
de plantas cultivadas, silvestres y animales. Encontrarse en el cerro y trabajarse "a mano". O ubicarse dentro de la casa como huerto, patio u otro. Lo real es que el ekuaro es un sistema multifuncional y megadiverso, que cubre todas las expectativas de los autores y productores, que puede clasificarse de acuerdo a su ubicación y tecnología en cuatro tipos.

\section{Ekuaro de solar}

\section{a) Tipo patio, solar, huertos o jardín}

Forma parte de la casa, como patio, traspatio o huerto. Su tamaño suele ser pequeño. Muchos de ellos tienen origen mesoamericano, los cuales, además de cumplir con las necesidades alimentarias y económicas inmediatas de sus propietarios, son sistemas etnoagroforestales tradicionales, cuyo origen es previo a la llegada de los europeos en el siglo XVI; que al confrontarse ocurrió un choque de ecosistemas primordiales entre el viejo y el nuevo mundo (Crosby, 2013). Actualmente actúa como repositorios de biodiversidad local, por la existencia de una mezcla dinámica de especies nativas útiles. La función principal de este ekuaro es el de proveer una fuente básica de alimento y productos comercializables para la familia, lo que es extremadamente importantes dadas las condiciones socioeconómicas que prevalecen hoy en México y Mesoamérica; pues en su interior existe una mezcla de especies nativas y exóticas, perennes y anuales, distribuidas en diferentes estratos que satisfacen las necesidades de los agricultores (Montagnini y Metzel, 2015; Cahuich-Campos et al., 2014).

Estos espacios, dependiendo del lugar donde se encuentren y tiempo de permanencia, adquieren nombres particulares. Por ejemplo, Guzmán (2005) menciona que en el estado de Morelos, las personas grandes platican que al patio le llamaban "callmil" y aclara que esta asignación se refiere más al cultivo de hortalizas en una cama formada con tierra y estiércol descompuesto y hojarasca, lo cual ya no se practica; y "calmill" (hortalizas en los solares), que es un pequeño lote o solar donde se siembran semillas y diversas variedades de maíz, calabaza, frijol, chile y flores. De manera similar se le denominan a los pequeños huertos que se ubican junto a la casa de los labradores (Palerm, 1997), y al pequeño ekuaro ubicado a un costado de la casa, donde se cultivan diversas estratos vegetacionales para usos particulares.
The corn crop is planted within it is to eat corn sweet and tender chew the cornstalks, whose varieties are usually: white, yellow, color, purple and red. The first is used to make tortillas and others to prepare some sweets and festive foods such as cornmeal (powdered toasted corn, sweetened with brown sugar and flavored with cinnamon, which can be eaten alone or gruel) and "tempoduro" (corn tan and confit with brown sugar), "uchepos" (corn tamales or sweet corn with brown sugar and carbonate) and corundas (tamale ash), michoacanos tamales whose production corn cooked with ash mesquite, butter and salt, and wrapped in green corn leaves. The ears of corn are cooked alone or accompanied with pumpkin and brown sugar. This ekuaro is intensive exploitation.

\section{Ekuaros on marginal lands or hills}

\section{a) Type ekuaro huamil}

Palerm (1997) mentions that the huamil (coa-cornfields: cornfield carved with sharp stick) is a recent introduction and spread in the state of Guanajuato, Mexico, but very old in Michoacán. It mentions the following: involves working to some uncultivated land, barren and marginal time; rangelands located in the old hacienda in the steep, rocky slopes of hills, and the rocky land and tepetate. Inaccessible not only to modern traction machines but also the plow, whose production of many peasant families gather not achieve the essential elements to meet their basic subsistence places. The huamil system was borrowed from the Tarascan Indian neighbors who practice it from time immemorial on the mountainous and dificult michoacano landscape, where it is known under the name tarasco ecuaro.

In the Morelia-Queréndaro valley, this traditional farming system is also called "by hand" because of the way to work it, as they are very rocky terrain, the cultivation method according to (Franco-Gaona et al. (2012), begins with "clean and arrangement of stones in lines perpendicular to the slope when the terrain permits or making holes in the stony ground to place the seed, perform work clean, harvesting and collection of organic waste, if possibleremoval, otherwise stover was left to enrich the soil ". The work done in this system is measured in "tasks". A task equivalent to planting corn, beans and squash in a space of 18 for 18 holes; i.e. excavate soil or make a hole with the spade and place three or four seeds of corn, beans and squash interleaving. Of this system he picked up the comment that "we continue sowing for pleasure to hoe, although I have irrigated land and work with the machine." 


\section{b) Ekuaro de explotación agroforestal continua asociado al ganado}

Es un espacio de aproximadamente una hectárea, circundado por una barda perimetral de piedra, en cuyo interior se encuentra ubicada la casa, el corral o establo del ganado mayor y los gallineros. En algunos puntos, circundando, dividiendo o fuera del terreno, se encuentran plantas cultivadas de nopal y magueyes pulqueros. Pegado a las bardas de piedra se ubican árboles maderables, frutales y de sombra. En su interior, rodeando a la casa y patio, se encuentra el ekuaro como terreno de cultivo, donde se siembra el maíz, asociado con frijol y haba, el cual se trabaja con la yunta o el tronco, pues ha sido despedrado.

El cultivo de maíz que se siembra en su interior es para comer elotes y masticar las tiernas cañas dulces de maíz, cuyas variedades suelen ser: blanco, amarillo, de color, morado y rojo. El primero es utilizado para elaborar las tortillas y los otros para preparar ciertos confites y alimentos festivos como: pinole (polvo de maíz tostado, endulzado con piloncillo y saborizado con canela, que puede comerse solo o en atole) y "tempoduro" (maíz de color tostado y confitado con piloncillo), "uchepos" (tamales de elote o de maíz tierno con piloncillo y carbonato) y corundas (tamal de ceniza), tamales michoacanos en cuya elaboración el maíz se cuece con ceniza de mezquite, manteca y sal, y se envuelven en hojas de maíz verde. Los elotes se cuecen solos o acompañados con calabaza y piloncillo. Este ekuaro es de explotación intensiva.

\section{Ekuaros en tierras marginales o cerriles}

\section{a) Ekuaro tipo huamil}

Palerm (1997) menciona que el huamil (coa-milpa: plantío de maíz labrado con palo afilado) es de reciente introducción y difusión en el estado de Guanajuato, México, pero muy antiguo en Michoacán. De él menciona lo siguiente: implica trabajar sobre tierras hasta cierto momento incultas, yermas y marginales; ubicadas en los viejos agostaderos de las haciendas, en las empinadas y rocosas pendientes de los cerros, y en las tierras pedregosas y de tepetate. Lugares inaccesibles no solo a las modernas máquinas de tracción sino también al arado, de cuya producción muchas familias campesinas no lograrían reunir los elementos indispensables para satisfacer sus necesidades de subsistencia básica. El sistema del huamil se tomó prestado de los vecinos indios tarascos quienes lo

\section{b) Ekuaro intensive cultivation of land}

It is commonly located on marginal land temporarily, larger than that used for huamil and mostly modernized, where the corn is grown using the yoke or trunk and work your way is familial. In its periphery stone fences dividing shade trees and timber, "nopales the hill" a kind of edible Opuntia, and weedy plants, where wood and other products for household consumption and trade are observed it is extracted. Usually they are grown continuously year or time. Usually this is associated ekuaro the house via cattle.

Linck (1982 and 1987) mentions that the fact of having an own plot with its traditional home, his small garden, its ecuaro or corral, with their economic implications, reinforces the membership of each domestic group to the community. Having this space favors labor activity and multiplies, because it is a space of a family, served outside everyday activities related to agriculture, which main activity is carried out or away from the house, as technology traditional it has not disappeared, because the integration of agriculture in the national economy is still too recent, so that their fingerprints are deleted entirely.

\section{Conclusions}

The ekuaro is a traditional ethnoagroforestry system multifunctional, rich in agricultural knowledgeand biodiversity that has persisted for over 500 years, part of the michoacana indigenous and mestizo family economy. It is polysemic as it is located inside the house as a family garden, yard, yard and/or plot in the house and outside it and the rocky hills with marginal land where it is grown "by hand" with use of the hoe, of where it is considered that migrated to neighboring states, acquiring own names, as in Guanajuato, known as huamil.

Asanextensionofhousingtheekuaro is preserved,itmaintained and resists the threat of population growth and public policies based on the paradigm of agricultural modernization, and attempts to show it as an unproductive space because it does not use its technology packages or their knowledge from the centers of public and private research. Because of its location, size and marginality only I could be managed and exploited traditional knowledge and technologies from indigenous and mestizo peasants with adherence to good living.

The ekuaro is a traditional ethnoagroforestry system due to the presence of vegetation with different strata, which is managed and utilized, particularly women and children. Due to its age 
practican desde tiempos inmemoriales sobre el montañoso y difícil paisaje michoacano, donde es conocido bajo el nombre tarasco de ecuaro.

En el valle Morelia-Queréndaro, a este sistema de cultivo tradicional también se le llama "de a mano", debido a la forma de trabajarlo, ya que son terrenos muy pedregosos, cuyo método de cultivo según (Franco-Gaona et al.(2012), inicia con "la limpia y acomodo de las piedras en líneas perpendiculares a la pendiente, cuando el terreno lo permite o realizando hoyos en el suelo pedregoso para colocar la semilla, realizar labores de limpia, cosecha y recolección de los residuos orgánicos, en el caso de que sea posible su extracción, de lo contrario, el rastrojo se dejaba para enriquecer el suelo". El trabajo que se realiza en este sistema se mide en "tareas". Una tarea equivale a sembrar maíz, frijol y calabaza en un espacio de 18 por 18 hoyos; es decir: excavar el suelo o hacer un hoyo con el azadón y colocar tres o cuatro semillas de maíz, intercalando frijol y calabaza. De éste sistema se recogió el comentario de que "lo continúo sembrando por gusto al azadón, a pesar de que tengo tierras de riego y trabajo con la máquina".

\section{b) Ekuaro de terreno de cultivo intensivo}

Comúnmente se encuentra ubicado en terrenos marginales de temporal, de mayor tamaño que el utilizado para el huamil y mayormente tecnificado, donde se cultiva la milpa utilizando la yunta o el tronco y su forma de trabajo es de tipo familiar. En su periferia se observan cercas divisorias de piedra con árboles de sombra y maderables, "nopales del cerro" una especie de Opuntia comestible, y plantas arvenses, de donde se extrae leña y otros productos para consumo del hogar y comercio. Suelen cultivarse de manera continua o en año y vez. Por lo común este ekuaro se encuentra asociado al de la casa vía ganado.

Linck (1982 y 1987) menciona que el hecho de poseer un solar propio con su casa tradicional, su pequeña huerta, su ecuaro o su corral, con sus respectivas implicaciones económicas, refuerza la membresía de cada grupo doméstico a la colectividad. Contar con este espacio favorece la actividad laboral y la multiplica, debido a que es un espacio de índole familiar, atendido fuera de las actividades cotidianas relacionadas con la agricultura, que como principal actividad, se desarrolla fuera o alejada de and evolution inside they have developed own varieties of corn, with the case of corn ekuaro or uarhuti, which is atrisk of disappearing. Its spatial and technological condition classify allowed: a) type ekuaro courtyard, plot, orchard or garden; and b) ekuaro of agroforestry associated with livestock; c) ekuaro huamil type; and d) ekuaro intensive cultivation ofland; which by its technological, economic and syncretic qualities he has transpired and demonstrated their effectiveness in providing satisfactions to their farmers; which in situ study you are needed to rescue their knowledge and propose conservation alternatives attached to the indigenous worldview.

End of the English version

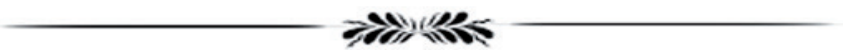

\section{Literatura citada}

Acosta,A. 2010. El buen vivir en el camino del post-desarrollo a la lectura desde la Constitución de Montecristi. Fundación Friedrich Ebert, FES-ILDIS. Ecuador. 43 p.

Aguilar, B. y Prieto, V. 2002. La troje: tipología de vivienda Purépecha. In: Petzet, M. and Ziesemer, J. (Comp.). Monumentos and sites. ICONOS ed. Munchen. 60-61 pp.

Alarcón-Chaires, P. 2009. Etnoecología de los indígenas Púrhepecha. Una guía para el análisis de la apropiación de la naturaleza. CIECO-UNAM. Morelia. $122 \mathrm{p}$.

Barrera-Bassols, N. 2003. Symbolism, knowledge and management of soil and land resources in indigenous communities: ethnopedology at global, regional and local scales. Vol II. Thesis Ph.D. in Earth Sciences. Faculty Sciences, Ghent University. ITC, Enschede, The Netherlands. 380 p.

Caballero, J. y Cortés, L. 2001. Percepción, uso y manejo tradicional de los recursos vegetales en México. Plantas, cultura y sociedad. Estudios sobre la relación entre seres humanos y plantas en los albores del siglo XXI. UAM/SEMARNAP. México. 79-100 pp.

Cahuich-Campos, D.; Huicochea G. L. y Mariaca M. R. 2014. El huerto familiar, la milpa y el monte maya en las prácticas rituales y ceremoniales de las familias de X-Mejía, Hopelchén, Campeche. Relaciones. 45(140):157-184.

Cárdenas del Río, L. 2003. 1985-1913. Anotaciones correspondientes hasta 1920.In: Lázaro Cárdenas.Apuntes. Una selección. Tomo 1. UNAM-Centro de Estudios de la Revolución Mexicana Lázaro Cárdenas, A. C. México. 22-58 pp.

CDI. 2006. Regiones indígenas de México. Distrito Federal, México: CDI-PNUD. 149 p.

Crosby, A. W. 2013. Gran historia como historia anbiental. Relaciones. 22(136):21-39.

Cruz, L. A.; Cervantes, H. M.; Damián, H.; Ramírez, V. B. y Ramírez, G. G. (2015). Etnoagronomía, tecnología agrícola tradicional y desarrollo rural. Rev. Geog. Agríc. 4(55):73-89.

Farrell, J. G. y Altieri, M. A. 1997. Sistemas agroforestales. In: agroecología. Bases científicas para una agricultura sustentable. CLADES/ACAO. La Habana, Cuba, 163 pp. 
la casa; y que la tecnología tradicional no ha desaparecido, porque la integración de la agricultura en la economía nacional es aún demasiado reciente como para que sus huellas se hayan borrado del todo.

\section{Conclusiones}

El ekuaro es un sistema etnoagroforestal tradicional multifuncional, rico en conocimientos agrícolas y biodiversidad que ha persistido por más de 500 años, formando parte de la economía familiar indígena y mestiza michoacana. Es polisémico ya que se encuentra dentro de la casa como huerto familiar, patio, traspatio y/o parcela en la casa y fuera de ella y en los cerros pedregosos con terrenos marginales donde se cultiva "a mano", con uso del azadón, de donde se considera que emigró hacia estados vecinos, adquiriendo nombres propios, como en Guanajuato, conocido como huamil.

Como extensión de la vivienda el ekuaro se conserva, mantiene y resiste a la amenaza del crecimiento poblacional y las políticas públicas basadas en el paradigma de la modernización agrícola, y a los intentos de mostrarlo como un espacio improductivo, porque no hace uso de sus paquetes tecnológicos, ni de sus conocimientos proveniente de los centros de investigación públicos y privados. Por su ubicación, tamaño y marginalidad solamente pude ser manejado y explotado con conocimientos y tecnologías tradicionales provenientes de los campesinos indígenas y mestizos con apego al buen vivir.

El ekuaro es un sistema etnoagroforestal tradicional, debido a la presencia de vegetación con diferentes estratos, que se maneja y aprovecha, particularmente, por mujeres y niños. Debido a su antigüedad y evolución, en su interior se han desarrollado variedades de maíz propias, siendo el caso del maíz de ekuaro o uarhuti, el cual se encuentra en riesgo de desaparecer. Su condición espacial y tecnológica permitió clasificarlo en: a) ekuaro tipo patio, solar, huerto o jardín; y b) ekuaro de explotación agroforestal asociado al ganado; c) ekuaro tipo huamil; y d) ekuaro de terreno de cultivo intensivo; que por sus cualidades tecnológicas, económicas y sincrética ha trascendido y demostrado su efectividad para proporcionar satisfactores a sus cultivadores; cuyo estudio in situ es necesario para rescatar sus saberes y proponer alternativas de conservación apegadas a la cosmovisión indígena.
Franco-Gaona, A.; Cruz León, A. y Ramírez-Valverde, B. 2012. Cambio tecnológico y tecnología comunitaria en El Valle MoreliaQueréndaro, Michoacán, México. Rev. Mex. Cienc. Agríc. 3(7):1305-1320.

Gilberti, M. F. 1901. Diccionario de la lengua Tarasca ó de Michoacán; impreso en México el año de 1559, reimpreso bajo la direccion y cuidado del Dr. Antonio Peñafiel. 44 p.

Godínez, C. M. del C. 2014. El "Ekuaro": un sistema sociológico resiliente. In: Basurto Peña, F. A. Simposio Metodología etnobotánica: avances y perspectivas. Universidad nacional Autónoma de México (UNAM)-IB. P. 69 p.

Guzmán, G. E. 2005. Resistencia, permanencia y cambio. Estrategias campesinas en el poniente de Morelos. México: Plaza y Valdez, S.A. de C. V. 321 p.

Krishnamurthy, L. y Ávila, M. 1999. Agroforestería básica. Serie textos básicos para la formación ambiental No. 3. PNUMA. FAO. México, D. F. 340 p.

Lathrop, M. 2007. Vocabulario del idioma Purépecha. 2a . (Ed.). Distrito Federal, México: Instituto Lingüistico de Verano, A. C. 153 p.

Linck, T. A. 1982. Estrategias campesinas y agropolítica: un caso en la meseta tarasca. Relaciones. 3(9):49-96.

Linck, T. A. 1987. La Meseta Tarasca bajo la ley del bosque. Relaciones. Estudios de Historia y Sociedad. 8(31):77-109.

Montagnini, F. y Metzel, R. 2015. Biodiversidad, manejo de nutrientes y seguridad alimentaria en huertos caseros. In: Montagnini, F. E. Sistemas agroforestales. Funciones productivas, socieconómicas y ambientales Colombia/Costa Rica: CIPAV/ CATIE. 381-404 pp.

Moreno-Calles, A. I.; Toledo, V. M. y Casas A. 2013. Los sistemas agroforestales tradicionales de México. Una aproximación biocultural. Bot. Sci. 91(4):375-398.

Moreno-Calles, A. I.; Jazmín Galicia-Luna, V.; Casas, A., Toledo, V. M.; Vallejo-Ramos, M.; Santos-Fita, D. y Camou-Guerrero,A. 2014. La Etnoagroforestería: el estudio de los sistemas agroforestales tradicionales de México. Etnobiología. 12(3):1-16.

Palerm, J. V. 1997. La persistencia y expansión de sistemas agrícolas tradicionales: el caso del huamil en el bajio mexicano. Minograf. Jard. Bot. Córdoba. (5):121-133.

Perdomo- Molina, A. C. 2013. Una propuesta desde la etnoagronomía para acercarnos a la agrodiversidad y la erosión genética de los sistemas tradicionales. Agroecología. 7(2):41-46.

Roskamp, H. 2003. Los códices de Cutzio y Huetamo: encomienda y tributo en la Tierra Caliente de Michoacán, siglo XVI. El Colegio de Michoacán, Zamora, Michoacán. 180 p.

Santos, B. de S. 2009. Una epistemología del sur: la reinvención del conocimiento y la emancipación social. Siglo XXI : CLACSO. Buenos Aires, Argentina. 368 p.

Sánchez, R. R. 2002. Paraisos terrenales. El riego en los pueblos huerteros michoacanos. Entre campos de esmeraldas: la agricultura de riego en Michoacán. El Colegio de Michoacán. Zanora, Michoacán. 77-102 pp.

Santana, R. 1986. Atapan: el paisaje urbano de un pueblo aguacatero. Relaciones. 7(25):135-156.

Uribe, S. J. A. 1996. Minería de cobre en el occidente del México prehispánico: un acercamiento historiográfico. Rev. India. 61(207):297-330 .

Urquidi, V. L. 1981. Tecnología y desarrollo rural: algunas reflexiones. Relaciones. Estudios de Historia y Sociedad. 2(7):107-136.

Wilken, G. C. 1987. Good farmers. Traditional agricultural resourse management in Mexico and Central America. University of California Press. California, USA. 302 p. 